\title{
notas sobre tudo aquilo que não está entre aspas
}

Tiago Monteiro

Nada havia.

Correção, nem mesmo o nada podia haver. Então, por um capricho do destino, ou talvez não exatamente do destino, mas de um de seus aspectos, que podemos chamar de sorte, azar, infortúnio, acaso, embriaguez ou qualquer coisa assim, de acordo com seu próprio ponto de vista, coisas aconteceram e, eis que o universo surgiu. E outras coisas aconteceram e outros universos surgiram. No nada pré-algo, tinha espaço de sobra e tempo de sobra pra toda e qualquer coisa acontecer, sem pressa e sem medo. Mas, a partir do momento inicial, tudo começou, e tudo começou junto. Aquele universo que conheci primeiro, criado a partir do vômito avermelhado sobre bolas de gude verdes por um guri magrelo e meio cegueta chamado deus, tinha em seu centro uma cidade prateada, morada do próprio deus e seus criados, criaturas de grande beleza e majestade. Saí da cidade por dois motivos: o menos importante, deus não me queria lá; o mais importante, eu não queria ficar lá, agora que tinha tanta coisa para ser vista. 
Caminhei por muito tempo entre rotas espaciais, galáxias e constelações sem fim, olhando toda a criação do meu antigo companheiro, arrumando uma coisa aqui e outra ali. Em alguns pontos, eu percebi que havia lugares estranhos.

Lugares em que as coisas pareciam apenas juntas, e não contínuas, como se fosse outro universo colado ao primeiro, e essas mudanças chamavam muito a minha atenção. Junto a uma dessas fronteiras, diretamente abaixo da cidade prateada de Deus, vi um outro lugar, interessante, também, mas de uma maneira distorcida. Imagine uma pintura muito bem executada e trabalhada pelo mestre artista; agora, imagine essa pintura copiada por uma criança entediada na aula de artes. Aos olhos do observador vulgar, essa cópia seria algo ridículo e infantil, digno de ser jogado fora. Aos olhos do professor de artes, é possível perceber onde a criança se esforçou e onde ela, de forma ainda incauta, criou.

Desci até essa sombra de cidade, observando os trabalhos de camadas que ela compunha, descendo em torno de si mesma. Não pude deixar de lembrar das escadas em espiral. Legal, eu pensei, e vi o universo à minha volta se adequar a um conceito recém-criado. Essa foi uma de minhas primeiras criações, da qual me orgulho muito. Algo legal é algo bacana, supimpa, maneiro, massa, da hora, divertido, fantástico, incrível, 10, entre outras várias traduções que podemos usar. Em suma, legal é um conceito que foi baseado nas escadas em espiral. Eu me lembrava delas e falava poxa, essa galáxia precisa de algo mais... algo como as escadas que deus fez, e mexia nelas até me sentir satisfeito. Legal, eu falava, e a galáxia, ou estrela, ou planeta, ou o que for que eu tinha modificado pensando nas escadas, piscava de volta pra mim e respondia Legal. 
Na entrada desta cidade na borda do primeiro universo havia um portão. Não sei se era porque aquele era o primeiro portão que eu vi, mas me surpreendi de maneira positiva: aquilo sim era um portão! Magnífico, enorme, imponente, quase expulsava qualquer visitante, e ainda assim, de tão poderoso em si mesmo, chegava a ser convidativo. Era uma armadilha para os olhos, para a mente e, mais tarde cheguei a descobrir, para todo o resto. Senti falta, porém, de algo que não soube dizer direito na hora o que poderia ser. Passei pelo portão e fui seguindo o caminho pela estrada em espiral que descia ao redor das camadas da cidade.

Ao andar por ela, descobri porque ela me era familiar: Lucy, o menino gorduchinho, a tinha feito, e copiou (daquele jeito infantil que comentei) a cidade de deus. Via seus assim chamados demônios andando por ela, fazendo o que se faz em qualquer cidade. Nenhum deles me importunou, na época eles ainda não tinham os instintos sádicos e mortais que hoje em dia são tão cansativamente esperados de um monstro. Gentilmente me apontaram o caminho onde eu poderia encontrar o pequeno Lu.

Desci até o último círculo, como os demônios chamavam a região onde seu criador morava, e logo vi o que certamente deveria ser sua casa, uma paródia do Palácio Divino, a casa de deus na Cidade Prateada, com a diferença de ser cercado por um lago. Seria um lugar bem aconchegante, se não fosse pelo estilo das construções. Entrei nos enormes salões da casa de Lu, e lá estava ele, sentado sobre um trono, tentando fazer cara de alguém sério e ocupado com seu reino e os problemas dele, coisa que (ainda) não havia. Quando entrei, ele se arrumou na cadeira, como uma criança que é pega fazendo algo de errado. Quase tudo poderia ser errado: que divertido! 
- Primeiro! O que você faz aqui? Perdeu a aposta do universo também? - uma não tão bem disfarçada surpresa acentuou sua vozinha aguda.

- Não, ainda estou no jogo. - vi um ar de frustração nos olhos dele ao receber esta notícia - Gostei do trabalho que você fez nessa cidade, viu? Até que você também tem alguma criatividade, não devia depender tanto assim dos outros, sabe? comentei, tentando amenizar o clima com o menino, que se irritava facilmente.

- A Cidade Inferior é muito melhor do que aquela que ele criou - o menino falou, com o despeito dos segundos lugares - e meu palácio inferior é bem maior também, como você pode ver.

De fato, enquanto os outros círculos da cidade compunham vários lugares, como que pequenas cidades em cada um. Já o último círculo era praticamente ocupado apenas pelo palácio de Lu, com o lago que o circundava.

- E você pretende ficar aqui para sempre? Não se importa nem um pouco em dar uma volta por aí, ver os lugares? - eu perguntei, tentando não sugerir nada.

- O que você está querendo sugerir? - ele se irritou, ficando em pé sobre o trono.

- Nada - eu disse.

Ele estava vermelho, bufando.

- Então eu não posso nem fazer minha cidade e ficar nela que todo mundo quer me criticar? - ok, aquilo ia ficar patético em um segundo - Agora eu tenho que ficar andando por aí, olhando a grandiosa criação de Deus? - eu não disse? - Me poupe, Primeiro!

Ele gesticulava os bracinhos gordos para dar ênfase a sua ironia e raiva, mas eu estava muito concentrado tentando não rir da cena para prestar atenção a isso. 
Procurando não alongar aquela conversa, já que é extremamente chato falar com quem quer sempre uma desculpa pra ficar zangado e brigar, elogiei mais uma vez a cidade dele e disse que tinha outros universos para visitar. Ao citar os outros universos, notei uma luz de curiosidade nos olhos dele, mas eu já não queria muita conversa, e, se ele quisesse mesmo conhecer, ele sairia e veria por conta própria. Eu não seria babá de ninguém.

Deixei para trás a cidade de Lu e voltei a passear pelos universos. Já que eu estava na borda entre um e outro, fui passear neste que ainda não tinha visto. Uma coisa importante de se perceber a respeito dessas fronteiras entre universos é que, assim como as fronteiras entre países, elas não circundam uma completude de coisas. Em geral, elas são uma zona transicional, se é que podemos simplificar. Basicamente, todo universo é igual, o que muda é a forma como eles são percebidos, ou como se dão a perceber aos diferentes tipos de seres. Com um pouco de atenção, caso você um dia viaje por aí para conhecer universos, é muito fácil notar as diferenças.

Um tom diferente no céu, uma ligeira mudança de temperatura, inversão nos polos magnéticos, algumas leis físicas diferentes... Acaba sendo bem fácil notar quando se passa de um universo a outro. Mesmo assim, como falei, as fronteiras são como zonas de transição, e uma mesma região fronteiriça pode conter em si propostas de inúmeros universos. É importante ter isso em mente, considerando que há lugares minúsculos com uma variedade tão grande de ideias que parecem ser frutos de uma mente não muito criativa, mas esperta em criação de conexões. São microbrainstorms, por assim dizer. Essas mudanças de universo me ajudavam cada vez mais a ter ideias a respeito do que se chama de criação. Como conheci pouca gente no antes de tudo, decidi sair em busca daqueles aspectos e demais possíveis criadores, considerando a grande profusão de diversidade de universos. 
Comecei, então, a procurar outras pessoas, talvez os criadores de cada região. Em alguns era fácil notar traços de personalidade nos universos, baseando em como o de Deus foi feito, e como Lu trabalhou na parte dele também. Com isso, dava pra imaginar que tipo de criador tinha trabalhado ali. E eu metia o bedelho, arrumando uma coisa aqui e outra ali. Não que as criações estivessem erradas (eu não tinha exatamente parâmetros para afirmar o que era certo ou errado nessa época, já que as linearidades e dualidades só vieram surgir bem depois de tudo isso; na verdade, bem depois do que o tempo foi criado), mas eu mudava uma ou outra coisa que eu achava que podia ser mudada, ou que ficaria mais legal. Porém, em outros universos, as coisas funcionavam de maneira estranha, como se não tivesse havido um criador propriamente, mas sim que as coisas pudessem talvez ter surgido de forma natural, de si mesmas, como se estivessem presas em alta pressão em um núcleo de massa infinita e tamanho infinitamente mínimo que não se aguentou e explodiu, espalhando-se pela imensidão do espaço, criando quase que instantaneamente o que hoje se chama de tempo. Sei lá, talvez fosse o criador daquele universo que tinha feito assim para que ninguém buscasse pensar nele e não o atrapalhassem, deixando tudo correr livremente, e que cada um fosse responsável por si.

Simpatizei com esse tipo de esperteza, claro. Mas achei razoavelmente covarde também. Que mal faria mostrar seu próprio trabalho pro pessoal? Andei por eternidades, procurando me distrair deixando o universo ainda mais maneiro. Em certo planeta, de constituição quase que completamente campestre, um dia eu pensei o que fazer pra deixar esta região mais legal?, e tive a ideia de fazer árvores. Depois do conceito de legal, acho que foi minha ideia mais brilhante, modéstia à parte. Vi aquele campo florido e selvagem, longo e ensolarado, e falei uma árvore aqui no meio seria legal, ainda mais pra ler um bom livro e tomar um suco. 
Assim, botei mãos à obra e, moldando aqui e ali, fiz uma árvore, e vi que a sombra dela era o que faltava para tudo ficar perfeito.

E aproveitei a brisa quentinha da tarde pra sentar ali e relaxar.

Enquanto eu repousava sob a sombra da minha nova árvore, encontrei Sundara. Ela eu ainda não tinha conhecido, mas o Jeff já tinha comentado a respeito. Eu estava quase cochilando, naquele calorzinho gostoso de primavera, observando o campo dourado e florido, com um ventinho agradável me acariciando, e ela apareceu e se sentou comigo. Era uma mocinha de beleza radiante e da qual a alegria emanava. Fiquei realmente alegre ao olhar pra ela. Ela ficou sentada ao meu lado, observando o campo e se divertindo com as voltas que o vento dava por entre seus cabelos. Percebi o porquê de seu nome ser Sundara. Combinava perfeitamente com ela. Tudo nela era bonito, era bom, era agradável. Então, ela olhou pra mim, e nada até então tinha sido mais belo e agradável. Nem mesmo as escadas em espiral.

E isso, vindo de mim, é um grande elogio.

- Oi - ela disse, sorrindo.

- Olá - eu respondi, embasbacado com o sentimento de alegria que me invadia.

- Qual o seu nome?

- Até agora só me chamaram de Primeiro, então acho que é esse o meu nome.

Ela me olhou com um ar preocupado.

- Não sei se esse é um bom nome. Quer um novo nome?

- Quero.

- Jeff é um bom nome. Que tal?

- O Segundo se chama Jeff. Acho que a velha que deu esse nome pra ele. 
- Ah, tinha que ser ela. - e Sundara fez um gracioso biquinho. - Ela sempre tem as boas ideias. Então vou te chamar de Jack. É um nome divertido também.

Um nome que o Ars iria gostar.

- Jack parece ser um nome bem legal. E o Ars é um cara legal também.

- Você conhece ele? Ele é demais!

Dizendo isso, ela se levantou, excitada por se lembrar de seu parente favorito, e começou a dançar. Fiquei observando a cena, pensando que todo mundo deveria ver isso pelo menos uma vez na vida.

- A propósito, sou Sundara.

- Eu sei... - eu respondi, num sussurro, ainda extasiado com toda a visão.

Ela sorriu mais uma vez e sumiu no meio das flores. Nem me levantei para procurála, pois sabia que não a encontraria. Pelo menos não tão cedo. Era assim com todos da família dela que eu já tinha encontrado até então, os esquisitos aspectos existenciais que encontrei no antes de tudo. Pois é, passear por aí arrumando coisas é divertido, mas depois de eternidades sozinho, sem ninguém para conversar, mesmo tendo árvores e campos para admirar, uma hora tudo acaba ficando chato, e a gente precisa de agito. $O$ encontro com Sundara só serviu pra mostrar que eu precisava de algo acontecendo, e após ela sumir, tomei a decisão de encontrar eventos para ver, participar e curtir.

Se você não faz ideia do tamanho do emaranhado de universos, acredite, é grande pra cacete! Imagine-se em uma cidade desconhecida, enorme, em um país cujo idioma você não fale, e onde ninguém pareça muito interessado em falar com você. 
Agora imagine que você quer encontrar um presente para a sua mãezinha, mas um presente significativo, que ela goste e que também conte a história dos lugares que você viu. Agora imagine que você não tem mãe, e nem sequer sabe que você conhece esse conceito, mas, ainda assim, precisa do presente. Só que você não sabe o que serve pra contar a história, nem como agradar sua mãe inexistente e sem conceito definido. E agora imagine que você não sabe quando volta pra casa, até porque esse é outro conceito que você não conhece. E imagine que é de madrugada, uma madrugada que dura semanas, mas, por algum motivo, você precisa encontrar algo pra sua mãezinha antes do seu avião partir na manhã seguinte, que você não sabe quando chegará. Só que você não tem mãe, nem casa, nem avião, nem nada disso que gere qualquer sentido de urgência em você. $E$ a cidade é simplesmente enorme, e está de madrugada e quase tudo está fechado. Mas você sabe, apenas, que tem que encontrar esse algo em que se prender. Acho que dá pra você entender mais ou menos como eu me sentia então.

Eu vaguei indefinidamente por muitos universos diferentes, cada um com suas características próprias, e todos eram interessantes, mas faltava algo importante neles. As coisas estavam lá, tudo bacana e funcionando, mas nada acontecia. Sentia falta de coisas acontecendo, sentia necessidade de eventos. Decidi, então, diminuir de escala e conhecer mais o que podia haver nos detalhes desses universos, e passei a andar de planeta em planeta, galáxia em galáxia, para tentar encontrar alguém pra conversar, alguém como eu, e ver se, em escala menor, havia eventos, coisas acontecendo. Queria ver como eram as coisas. Mas essa busca não era algo fácil - tediosa é um jeito de descrevê-la com mais veracidade - pois era muito demorada. Mas eu tinha tempo, ou melhor, eternidades para isso. E, para quem conheceu o tédio sem fim do nada antes de qualquer coisa existir, aquilo ali era um passeio de domingo. 
Até que, em uma galáxia muito distante, senti uma espécie de mensagem, e aquele universo dizia:

- Ei, Jack, você sabia que inventaram o tempo?

- Tempo? Mas já?

É bom que se compreenda que medidas espaciais e temporais ainda não tinham sido inventadas na prática, mas as palavras sobre elas surgiram desde antes do próprio universo, então é muito claro que as coisas simplesmente se apropriaram ao vocabulário existente, como quem compra uma roupa de segunda mão. Porém, quando algo como o tempo é inventado, merece uma visitinha para entender exatamente como que ele funcionava. Assim, rumei para as regiões mais ligadas nas últimas modas dos universos, que já tinham adquirido a nova sensação do momento, o tempo. 